OPEN ACCESS

Edited by:

David I. Rosenthal,

University of Texas MD Anderson

Cancer Center, United States

Reviewed by: Cesare Piazza

University of Brescia, Italy Markus Brunner,

Medical University of Vienna, Austria

*Correspondence: Geoffrey E. Rose geoff.rose@moorfields.nhs.uk

Specialty section: This article was submitted to Head and Neck Cancer, a section of the journal

Frontiers in Oncology

Received: 08 February 2017 Accepted: 29 May 2017

Published: 23 June 2017

Citation:

Rose AM, Cowen S, Jayasena CN, Verity DH and Rose GE (2017)

Presentation, Treatment, and Prognosis of Secondary Melanoma within the Orbit. Front. Oncol. 7:125. doi: 10.3389/fonc.2017.00125

\section{Presentation, Treatment, and Prognosis of Secondary Melanoma within the Orbit}

\author{
Anna M. Rose ${ }^{1,2}$, Sophie Cowen ${ }^{3}$, Channa N. Jayasena ${ }^{2}$, David H. Verity ${ }^{3}$ \\ and Geoffrey E. Rose $e^{1,3 *}$ \\ ${ }^{1}$ UCL Institute of Ophthalmology, London, United Kingdom, ${ }^{2}$ Department of Medicine, Imperial College, London, \\ United Kingdom, ${ }^{3}$ Orbital Unit, Moorfields Eye Hospital, London, United Kingdom
}

Background: Ocular melanoma is a rare but often deadly malignancy that arises in the uvea, conjunctiva, or orbit. Uveal melanoma is the most common type, with conjunctival melanoma being the second most frequently observed. Melanoma accounts for $5-10 \%$ of metastatic or secondary orbital malignancies, but only a minute proportion of primary orbital neoplasia. The aim of this study was to characterize the clinical presentation, treatment, and prognosis in patients presenting with melanoma metastatic to, or secondary within, the orbit.

Methods: A retrospective cohort study of patients presenting to a tertiary referral orbital unit from 1982 to 2016 was performed. Eighty-nine patients with biopsy-proven diagnosis of melanoma within the orbit were included in the study. The clinical notes, radiological imaging, histology, surgical notes, and outcome data for the patients were reviewed. The main outcome measures of interest were the interval between primary malignant melanoma and orbital presentation, survival after orbital presentation, and clinical parameters (such as gender, age at presentation, and treatment approach).

Results: The commonest primary source of tumor was choroidal melanoma, with conjunctival and cutaneous melanomas being relatively common; eyelid and naso-sinus tumors occurred in a few cases. The mean age at presentation with orbital disease was 65 years (31-97 years). The interval between primary malignancy and orbital disease (either local spread/recurrence or true metastatic disease) showed wide variability, with almost one-third of patients having orbital disease at the time of primary diagnosis, but others presenting many years later; indeed, the longest orbital disease-free interval was over 34 years. Twenty-three patients were considered to have had late orbital metastases - that is, at more than 36 months after primary tumor. The median survival following presentation with orbital involvement was 24 months. Patients with tumors of cutaneous origin had worst survival, whereas those with conjunctival tumors had the best prognosis.

Conclusion: A high index of suspicion for orbital recurrence should be maintained in any patient with prior history of melanoma, however distant the primary tumor is in site or time. Furthermore, giving a prognosis for orbital melanoma remains problematic due to highly variable survival, and further investigation will be necessary to understand the likely genetic basis of this phenomenon.

Keywords: melanoma, orbital tumors, orbital malignancy, orbital metastases, metastatic melanoma 


\section{INTRODUCTION}

Intraocular metastases from malignant melanomas usually affect sites favored by primary intraocular melanoma-namely, the uveal tract-but can also affect the optic disc, retina, and vitreous (1-5). Orbital metastases from any malignancy are rare, and metastatic melanoma accounts for $5-20 \%$ of these, with primary sites usually being the skin, uvea, or ocular surface (6-11). Late presentation of secondary orbital melanoma has occasionally been reported, with the longest disease-free interval being 40 years after enucleation for a choroidal melanoma (12), but in general, these patients have been reported to have very poor survival-the average being 5.7-19.7 months $(10,13,14)$.

In this work, we extend the knowledge of the clinical presentation and therapeutic strategies for patients with secondary melanoma within the orbit, including patients with anatomically contiguous disease (e.g., local progression or local recurrence of ipsilateral ocular disease/sinus disease) and those with true metastatic disease (e.g., contralateral ocular disease or distant cutaneous sites). In particular, focus is placed on two unusual groups: first, those patients with a long interval between primary disease and orbital disease and, second, those with a long survival after treatment of melanoma within the orbit.

\section{PATIENTS AND METHODS}

Patients seen within the Orbital Unit at Moorfields Eye Hospital, between 1982 and 2016, with biopsy-proven orbital melanoma were identified from a diagnostic database, and the clinical casenotes and imaging were reviewed (where available). Patients with proven primary orbital melanoma (e.g., without evidence of ipsilateral intraocular, ocular surface, or sinus disease) were excluded. For this study, "late" orbital recurrence was regarded as being 3 or more years after treatment of the primary tumor, and "long survival" was 4 or more years after diagnosis of secondary orbital disease. The study was conducted in accordance with the Declaration of Helsinki. All participants had given written, informed consent for inclusion of data in studies prior to surgery or treatment. Local ethics board (Moorfields Eye Hospital NHS Foundation Trust) approved the study under the retrospective analysis of data procedures (ROAD17/010).

Survival analysis was estimated using standard Kaplan-Meier survival plots (on MedCalc); normality of data was assessed using Shapiro-Wilks testing, and comparison of means was performed using Mann-Whitney $U$-testing for non-parametric data.

\section{RESULTS}

Eighty-nine patients were identified with secondary orbital melanoma during the study period, with complete clinical data available for 48 (54\%) patients (Table 1), and partial data-including mortality data-for a further 21 patients (24\%) (Table 2); only very limited data were available for 20 patients. The commonest primary source of tumor was choroidal melanoma $(45 / 89 ; 51 \%)$; conjunctival melanoma was the next most frequent (15/89; $17 \%)$, and cutaneous, eyelid, and naso-sinus tumors occurred in a few cases; the primary origin could not be ascertained in $11 / 89(12 \%)$ cases due to disseminated disease at presentation (Figure 1). The mean age at presentation with secondary orbital disease was 65 years (median 63; range 31-97 years). There was no significant gender bias, with 50 affected women and 39 men $\left(\chi^{2}=2.72, p>0.05\right)$; this lack of gender bias persisted after being stratified by the decade of presentation $(p>0.05)$. Most patients were white northern Europeans, but four were of Mediterranean origin, one from the Middle East, and one from North Africa.

The interval between the diagnosis of primary tumor and the later detection of orbital disease (the "orbital disease-free interval") was available for $48 / 89$ (54\%) patients. This showed a wide variation, with $13 / 48$ (27\%) patients having orbital disease found at the time of primary diagnosis, but others presenting many years later; indeed, the longest orbital disease-free interval was over 34 years (Table 1; Figure 2). Twenty-three (23/48; 48\%) patients were considered to have had late orbital disease-that is, at more than 36 months after primary tumor-and 17/23 (74\% of the late recurring tumors) had very late recurrence ( $>6$ years after primary disease). The commonest primary origin for late recurrent orbital tumors was skin $(9 / 23$ cases; $39 \%)$ or uveal tract $(8 / 23 ; 35 \%)$.

Of 69 patients whose mortality data were available in May 2016, 52 had died (47/52 known tumor-related deaths) at a median of 24 months after orbital diagnosis (range 2 months to 33.2 years). Patients with tumors of cutaneous or unknown origin had worst survival, conjunctival had the best, and choroidal had the second best survival (Figure 3). There was no correlation between the orbital disease-free interval and overall survival $(r=-0.16$; one outlier value excluded) (Figure 4). The overall survival after orbital disease patients was similar in patients with early and late orbital recurrence $(U=162, Z=-0.399, p=0.689)$; this latter analysis was performed excluding any patients presenting after May 2012 to avoid bias favoring the "early-recurring" group. Furthermore, the patients with locally progressive or locally recurrent secondary disease had similar survival to that of the patients with metastatic secondary disease $(U=97.5, Z=0.400$, $p=0.690$ ). The median follow-up for the 17 known living patients is 44 months (range 1-190 months), suggesting a relatively good survival in this group.

Sixteen patients survived 4 years or more after orbital diagnosis (range 52-398 months), and eight are still alive (surviving to-date 52-190 months); the primary tumor was from choroid (eight cases), conjunctiva (four cases), skin (two cases), or sinus (two cases).

\section{Surgical Approaches in Secondary Orbital Melanoma}

Where imaging showed diffuse orbital disease, an incisional biopsy was performed without any mobilization of bone, and, where orbital disease was causing major disfigurement, the patient was later considered for palliative orbital exenteration. However, in many cases, secondary orbital melanoma formed a well-defined mass at the time of presentation, and, in such cases, the mass was excised intact through a bone-sparing anterior orbitotomy. Where macroscopically intact excision was not possible, the lesion was, as far as possible, meticulously isolated from the 
TABLE 1 | Clinical characteristics of 48 patients with orbital malignant melanoma secondary to a primary tumor elsewhere, classified by the site of primary tumor and the survival interval after presentation with orbital disease.

\begin{tabular}{|c|c|c|c|c|c|c|c|c|c|c|c|c|}
\hline Sex & $\begin{array}{l}\text { Site of primary } \\
\text { tumor }\end{array}$ & $\begin{array}{c}\text { Age at } \\
\text { presentation } \\
\text { with primary } \\
\text { tumor }\end{array}$ & $\begin{array}{l}\text { Therapy for primary } \\
\text { tumor }\end{array}$ & $\begin{array}{l}\text { Age at } \\
\text { secondary } \\
\text { orbital } \\
\text { disease } \\
\text { (years) }\end{array}$ & $\begin{array}{l}\text { Interval } \\
\text { between } \\
\text { primary } \\
\text { therapy } \\
\text { and orbital } \\
\text { presentation } \\
\text { (months) }\end{array}$ & Side & $\begin{array}{l}\text { Treatment for secondary orbital } \\
\text { disease }\end{array}$ & $\begin{array}{l}\text { Orbital } \\
\text { progression }\end{array}$ & $\begin{array}{l}\text { Systemic } \\
\text { progression }\end{array}$ & $\begin{array}{l}\text { Interval } \\
\text { between } \\
\text { primary } \\
\text { therapy } \\
\text { and latest } \\
\text { follow-up } \\
\text { (months) }\end{array}$ & $\begin{array}{c}\text { Survival } \\
\text { after orbital } \\
\text { treatment } \\
\text { (months) }\end{array}$ & $\begin{array}{c}\text { Age at } \\
\text { death } \\
\text { (years) }\end{array}$ \\
\hline M & Choroid & 77 & Enucleation & 79 & 32 & L & Palliation & & & 34 & 2 & 79 \\
\hline $\mathrm{F}$ & Choroid & 89 & Incisional biopsy & 89 & 0 & L & Incisional biopsy & $N$ & Y & 3 & 3 & 89 \\
\hline $\mathrm{F}$ & Choroid & 73 & Incisional biopsy & 73 & 0 & L & Incisional biopsy + RT & N & N & 14 & 14 & 75 \\
\hline M & Choroid & 49 & Local resection & 72 & 282 & L & Debulking + chemotherapy & Y & Y & 299 & 17 & 73 \\
\hline M & Choroid & 47 & Enucleation & 57 & 114 & $\mathrm{R}$ & Radiotherapy & & & 138 & 24 & 58 \\
\hline $\mathrm{F}$ & Choroid & 69 & Enucleation & 69 & 6 & $\mathrm{R}$ & Exenteration & N & Y & 30 & 24 & 71 \\
\hline $\mathrm{F}$ & Choroid & 68 & Exenteration + RT & 68 & 0 & $\mathrm{R}$ & (Exenteration + RT) & U & U & 24 & 24 & 70 \\
\hline $\mathrm{F}$ & Choroid & 67 & Enucleation + RT & 67 & 1 & L & Debulking & Y & N & 26 & 25 & 69 \\
\hline M & Choroid & 37 & Refused therapy & 41 & 49 & $\mathrm{R}$ & Exenteration + RT & Y & Y & 84 & 35 & 43 \\
\hline $\mathrm{F}$ & Choroid & 72 & Palliation & 72 & 0 & L & (Palliation) & $\mathrm{N}$ & Y & 39 & 39 & 75 \\
\hline $\mathrm{F}$ & Choroid & 53 & Enucleation & 54 & 11 & $\mathrm{R}$ & Exenteration + RT & N & Y & 53 & 42 & 57 \\
\hline $\mathrm{F}$ & Choroid & 59 & Exenteration & 59 & 0 & $\mathrm{R}$ & (Exenteration) & $N$ & Y & 56 & 56 & 63 \\
\hline M & Choroid & 23 & $\mathrm{RT}$ & 44 & 262 & L & Debulking + RT & Y & Y & 322 & 60 & 49 \\
\hline M & Choroid & 71 & Enucleation & 71 & 0 & $\mathrm{R}$ & (Enucleation) & N & N & 105 & 105 & 80 \\
\hline M & Choroid & 63 & Exenteration + RT & 63 & 0 & $\mathrm{R}$ & $($ Exenteration + RT) & $N$ & $N$ & 134 & 134 & 74 \\
\hline M & Choroid & 60 & Enucleation & 62 & 25 & L & Exenteration & $N$ & $N$ & 184 & 159 & 75 \\
\hline$M$ & Choroid & 5 & Enucleation & 39 & 416 & $\mathrm{R}$ & Exenteration & $\mathrm{N}$ & $\mathrm{N}$ & 814 & 398 & 72 \\
\hline $\mathrm{F}$ & Choroid & 62 & Exenteration + RT & 62 & 0 & $\mathrm{R}$ & (Exenteration + RT) & N & N & 17 & 17 & N/A \\
\hline $\mathrm{F}$ & Choroid & 41 & Exenteration + RT & 41 & 0 & L & Exenteration + RT & N & Y & 30 & 30 & N/A \\
\hline M & Choroid & 41 & Enucleation & 60 & 239 & $\mathrm{R}$ & Debulking + RT & N & N & 412 & 173 & N/A \\
\hline $\mathrm{F}$ & Choroid & 36 & Enucleation & 53 & 208 & $\mathrm{R}$ & Excisional biopsy $+\mathrm{RT}$ & Y & N & 398 & 190 & N/A \\
\hline M & Choroid & 48 & Enucleation & 49 & 16 & L & Exenteration & $\mathrm{N}$ & Y & & $\begin{array}{l}\text { Lost to } \\
\text { follow-up }\end{array}$ & $\begin{array}{l}\text { Died date } \\
\text { unknown }\end{array}$ \\
\hline $\mathrm{F}$ & Choroid & 54 & RT & 58 & 56 & L & Exenteration + RT & N & N & & $\begin{array}{l}\text { Lost to } \\
\text { follow-up }\end{array}$ & $\begin{array}{l}\text { Died date } \\
\text { unknown }\end{array}$ \\
\hline $\mathrm{F}$ & Conj & 70 & Exenteration & 70 & 0 & $\mathrm{R}$ & Exenteration & $N$ & Y & 2 & 2 & 70 \\
\hline $\mathrm{F}$ & Conj & 82 & Excisional biopsy & 82 & 8 & $\mathrm{R}$ & Exenteration & U & Y & 46 & 38 & 71 \\
\hline M & Conj & 55 & Local resection & 56 & 12 & $\mathrm{R}$ & Excisional biopsy & Y & Y & 208 & 196 & 73 \\
\hline $\mathrm{F}$ & Conj & 87 & Local resection + RT & 97 & 120 & L & Exenteration & N & N & 124 & 4 & N/A \\
\hline
\end{tabular}


TABLE 1 | Continued

\begin{tabular}{|c|c|c|c|c|c|c|c|c|c|c|c|c|}
\hline Sex & $\begin{array}{l}\text { Site of primary } \\
\text { tumor }\end{array}$ & $\begin{array}{c}\text { Age at } \\
\text { presentation } \\
\text { with primary } \\
\text { tumor }\end{array}$ & $\begin{array}{l}\text { Therapy for primary } \\
\text { tumor }\end{array}$ & $\begin{array}{l}\text { Age at } \\
\text { secondary } \\
\text { orbital } \\
\text { disease } \\
\text { (years) }\end{array}$ & $\begin{array}{l}\text { Interval } \\
\text { between } \\
\text { primary } \\
\text { therapy } \\
\text { and orbital } \\
\text { presentation } \\
\text { (months) }\end{array}$ & Side & $\begin{array}{l}\text { Treatment for secondary orbital } \\
\text { disease }\end{array}$ & $\begin{array}{l}\text { Orbital } \\
\text { progression }\end{array}$ & $\begin{array}{l}\text { Systemic } \\
\text { progression }\end{array}$ & $\begin{array}{l}\text { Interval } \\
\text { between } \\
\text { primary } \\
\text { therapy } \\
\text { and latest } \\
\text { follow-up } \\
\text { (months) }\end{array}$ & $\begin{array}{l}\text { Survival } \\
\text { after orbital } \\
\text { treatment } \\
\text { (months) }\end{array}$ & $\begin{array}{c}\text { Age at } \\
\text { death } \\
\text { (years) }\end{array}$ \\
\hline M & Conj & 69 & Local resection + RT & 75 & 80 & $\mathrm{R}$ & Exenteration + chemotherapy & N & Y & 87 & 7 & N/A \\
\hline M & Conj & 65 & Local resection & 69 & 51 & $\mathrm{R}$ & Excisional biopsy & $\mathrm{N}$ & $\mathrm{N}$ & 70 & 29 & N/A \\
\hline $\mathrm{F}$ & Conj & 48 & Local resection & 59 & 128 & $\mathrm{R}$ & Exenteration & $\mathrm{N}$ & $\mathrm{Y}$ & 164 & 36 & N/A \\
\hline $\mathrm{F}$ & Conj & 65 & Local resection + RT & 65 & 11 & L & Debulking & Y & Y & 63 & 52 & N/A \\
\hline M & Conj & 87 & Exenteration & 87 & 0 & $\mathrm{R}$ & Exenteration & $\mathrm{N}$ & Y & 59 & 59 & N/A \\
\hline $\mathrm{F}$ & Conj & 60 & Nil & 61 & 6 & L & Exenteration & $\mathrm{N}$ & $\mathrm{N}$ & 246 & 240 & N/A \\
\hline M & Skin & 36 & Local resection & 43 & 87 & L & Debulking + chemotherapy & $\mathrm{N}$ & Y & 89 & 2 & 43 \\
\hline $\mathrm{F}$ & Skin & 44 & Local resection & 63 & 234 & L & Excisional biopsy & $\mathrm{N}$ & Y & 240 & 6 & 64 \\
\hline $\mathrm{F}$ & Skin & 58 & Palliation & 58 & 0 & $\mathrm{R}$ & Palliation & N & Y & 8 & 8 & 58 \\
\hline M & Skin & 86 & Local resection & 88 & 28 & $\mathrm{R}$ & Palliation & Y & Y & 36 & 8 & 88 \\
\hline $\mathrm{F}$ & Skin & 51 & Local resection & 57 & 83 & L & Incisional biopsy + chemotherapy & $\mathrm{N}$ & Y & 96 & 13 & 59 \\
\hline M & Skin & 31 & Local resection & 34 & 52 & BOTH & Extensive resection & $U$ & $U$ & 72 & 20 & 36 \\
\hline M & Skin & 51 & Local resection & 60 & 121 & $\mathrm{R}$ & Biopsy + chemotherapy & $\mathrm{N}$ & Y & 142 & 21 & 62 \\
\hline $\mathrm{F}$ & Skin & 32 & Local resection & 64 & 362 & L & Exenteration & $\mathrm{N}$ & $\mathrm{N}$ & 363 & 1 & N/A \\
\hline $\mathrm{F}$ & Skin & 54 & Local resection & 60 & 79 & L & Exenteration + RT & $\mathrm{N}$ & $\mathrm{N}$ & 87 & 8 & N/A \\
\hline M & Skin & 54 & Local resection & 71 & 205 & L & Debulking & & Y & 295 & 90 & N/A \\
\hline $\mathrm{F}$ & Skin & 65 & Local resection & 67 & 41 & $R$ & Debulking + RT & $\mathrm{N}$ & Y & 191 & 150 & N/A \\
\hline M & Unknown & 61 & Palliation & 61 & 0 & $\mathrm{R}$ & Palliation & $\mathrm{N}$ & Y & 4 & 4 & 61 \\
\hline $\mathrm{F}$ & Nasal & 54 & Local resection & 67 & 161 & L & Debulking & Y & Y & 201 & 45 & 71 \\
\hline $\mathrm{F}$ & Nasal & 57 & Local resection & 61 & 48 & L & Debulking + RT & $U$ & Y & 101 & 53 & 64 \\
\hline $\mathrm{F}$ & Sinus & 59 & Local resection & 59 & 1 & L & Debulking + RT & N & N & 100 & 99 & $\mathrm{~N} / \mathrm{A}$ \\
\hline
\end{tabular}

$R T$, radiotherapy.

Gray shaded cases can be considered truly metastatic disease, whilst non-shaded cases are likely to represent local spread or local micrometastasis. 
TABLE 2 | Survival after presentation with secondary orbital melanoma in 21 patients for whom date of death is known, without other complete clinical data; classified by origin of the primary tumor.

\begin{tabular}{|c|c|c|c|c|}
\hline Sex & $\begin{array}{c}\text { Age at orbital } \\
\text { presentation } \\
\text { (years) }\end{array}$ & $\begin{array}{l}\text { Site of primary } \\
\text { melanoma }\end{array}$ & $\begin{array}{l}\text { Age at } \\
\text { death } \\
\text { (years) }\end{array}$ & $\begin{array}{c}\text { Survival after } \\
\text { presentation with } \\
\text { secondary orbital } \\
\text { disease (months) }\end{array}$ \\
\hline M & 57 & Choroid & 58 & 8 \\
\hline $\mathrm{F}$ & 82 & Choroid & 83 & 20 \\
\hline$M$ & 64 & Choroid & 64 & 20 \\
\hline$M$ & 63 & Choroid & 66 & 38 \\
\hline$M$ & 54 & Choroid & 57 & 42 \\
\hline $\mathrm{F}$ & 86 & Choroid & 91 & 66 \\
\hline $\mathrm{F}$ & 75 & Choroid & 85 & 125 \\
\hline $\mathrm{F}$ & 47 & Choroid & 74 & 328 \\
\hline$M$ & 63 & Conjunctiva & 64 & 21 \\
\hline $\mathrm{F}$ & 81 & Conjunctiva & 83 & 32 \\
\hline $\mathrm{F}$ & 60 & Conjunctiva & 65 & 63 \\
\hline M & 78 & Conjunctiva & 90 & 140 \\
\hline $\mathrm{F}$ & 64 & Nasal & 64 & 1 \\
\hline M & 63 & Sinus & 63 & 3 \\
\hline $\mathrm{F}$ & 53 & Unknown & 53 & 3 \\
\hline$M$ & 61 & Unknown & 60 & 5 \\
\hline $\mathrm{F}$ & 62 & Unknown & 64 & 25 \\
\hline $\mathrm{F}$ & 75 & Unknown & 78 & 50 \\
\hline $\mathrm{F}$ & 63 & Unknown & 69 & 70 \\
\hline $\mathrm{F}$ & 67 & Unknown & 73 & 73 \\
\hline$M$ & 87 & Unknown & 70 & 89 \\
\hline
\end{tabular}

Patients classified as having "unknown" origin for their primary tumor had extensive systemic disease at presentation and poorly differentiated histology, this precluding a conclusive diagnosis of the primary site.

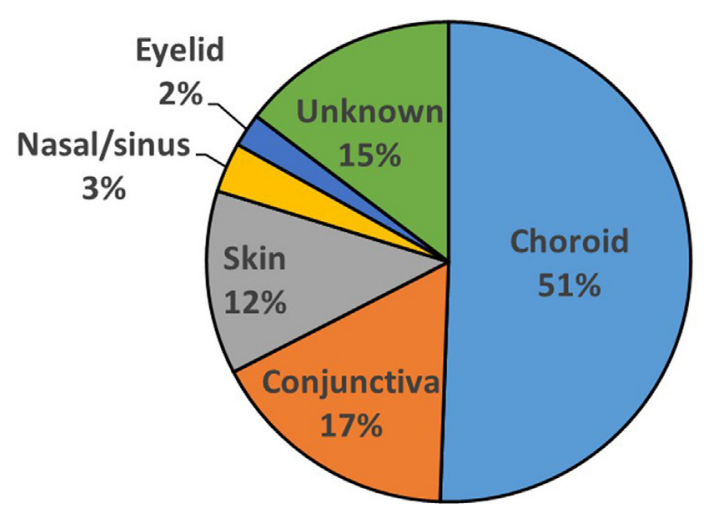

FIGURE 1 | Sites of primary origin for malignant melanomas for 89 patients presenting with melanoma in the orbit.

"normal" neighboring tissues, and then piecemeal excision of the mass (debulking) was performed.

\section{DISCUSSION}

A retrospective analysis has been performed for 89 patients presenting with biopsy-proven secondary orbital melanoma in a tertiary-referral orbital unit; this analysis included two closely related classifications of secondary orbital of tumor-those that were locally progressive/recurrent and those that had metastasized from distant sites. There were two notable features in the

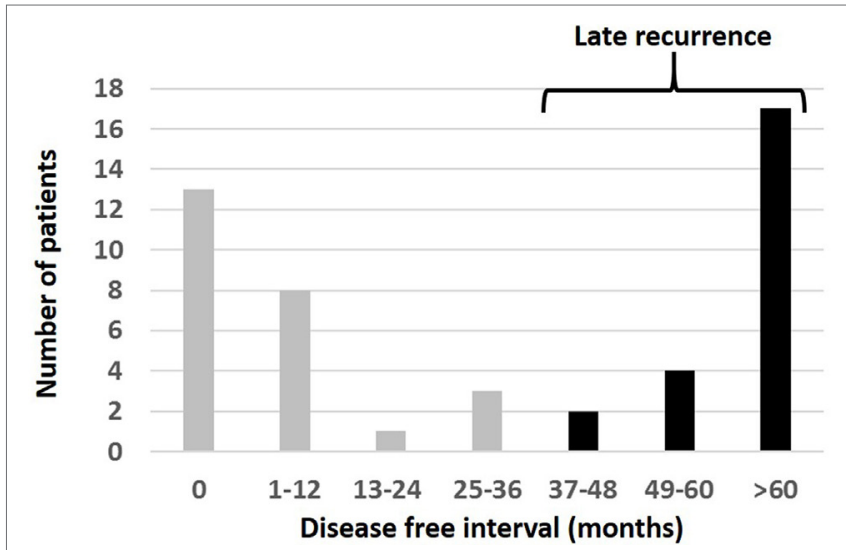

FIGURE 2 | Interval from the time of diagnosis of primary melanoma to the appearance of orbital disease in 48 patients presenting with melanoma in the orbit. Patients were considered to have "late recurrence" when orbital disease presented more than 3 years after the primary diagnosis elsewhere.
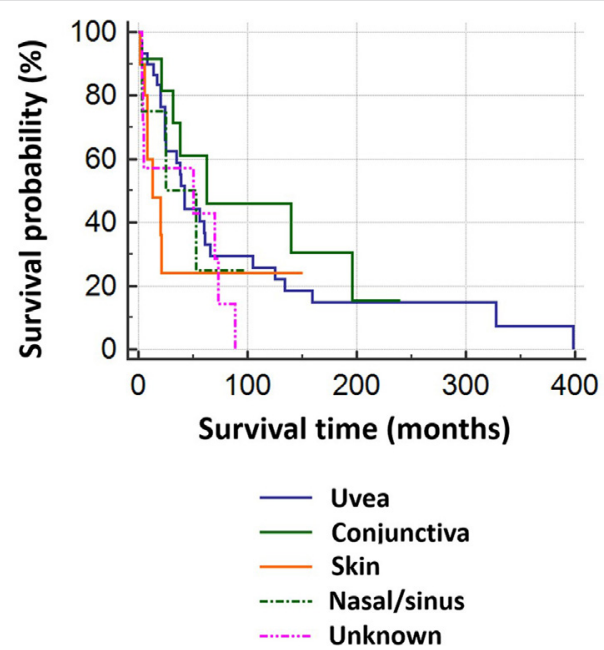

FIGURE 3 | Kaplan-Meier survival analysis for 69 patients with orbital melanoma secondary to primary disease at another site, classified by origin of the primary tumor.

patient group: first, orbital involvement tends to occur either early ( $<1$ year after primary disease) or late at many years after primary disease (Figure 2). Second, there was a group of patients with an unusually long survival after the diagnosis of melanoma recurrence within the orbit.

Thirteen patients had orbital melanoma as the presenting symptom of a primary melanoma arising elsewhere; 11 of these were-somewhat predictably-ocular primary tumors with local disease progression; one primary tumor was, however, a distant cutaneous lesion, and one patient had widespread systemic disease and thus primary origin was not discernible. Late recurrence of choroidal melanoma is, however, fairly common-with $9 \%$ of recurrences occurring at 5-10 years after treatment (15). Of our 48 patients with complete follow-up, the time from initial diagnosis to presentation with orbital disease varied from 0 months 


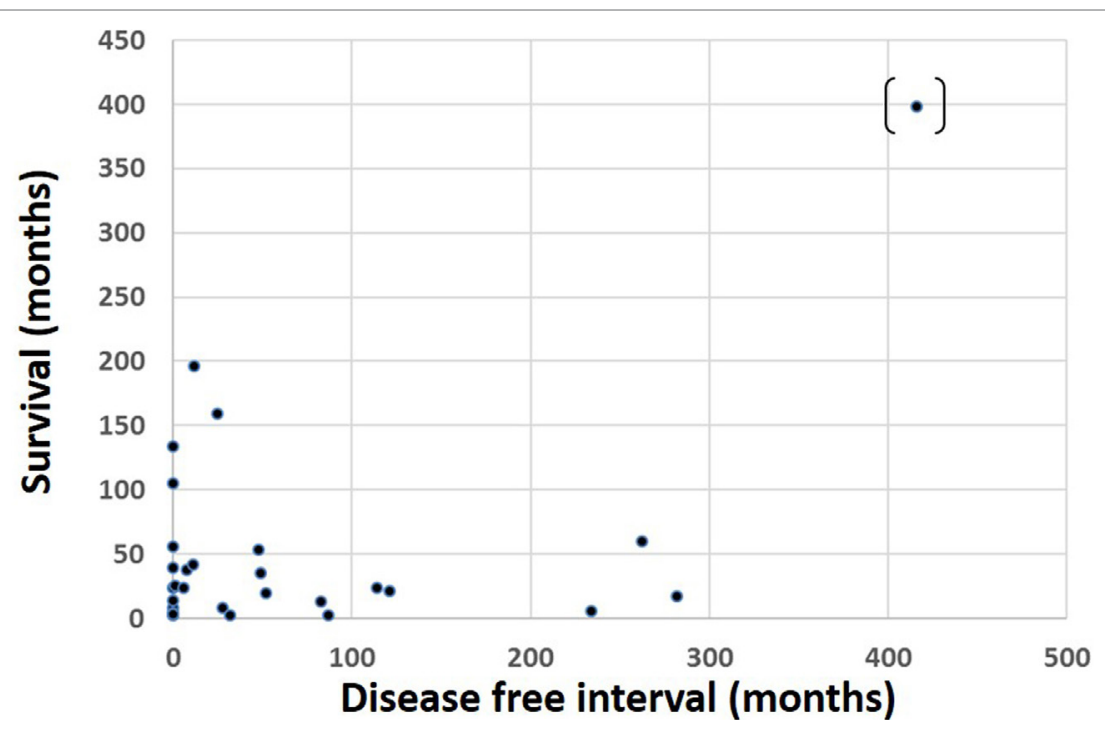

FIGURE 4 | Survival time after presentation with orbital disease in 69 patients, as related to the interval between primary tumor diagnosis and orbital presentation.

to $>34$ years; remarkably, $23 / 48(48 \%)$ had late secondary local recurrence, with an interval of 36 months or more between primary disease and orbital recurrence. This propensity for late orbital recurrence might, therefore, suggest that a disease-free interval of 10 years should not be considered a definite "cure" for malignant melanoma.

The reason for the long interval between primary disease and orbital recurrence in our patients is conjectural, but it might be related to immune-mediated control of tumor growth. Tumor-specific lymphocytes that target malignant cells through recognition of tumor-associated antigens-such as tyrosinase, Melan-A/MART-1, gp100, TRP-1, and TRP-2-have been isolated from melanoma (16). Furthermore, melanomas showing spontaneous regression contain more tumor-specific lymphocytes than those in non-regressing tumors, and the presence of these lymphocytes portends a better prognosis $(17,18)$. High levels of immunosurveillance within the orbit might, therefore, maintain micro-metastases of primary tumor in remission for many years; later, mutations might occur in tumor-associated antigens, leading to loss of lymphocytic recognition and, thereby, loss of tumor control. Alternatively, detrimental changes in the immune system (such as pregnancy, immunocompromise, or aging) might lead to reduced efficiency of immune surveillance, with emergence of growth in previously well-controlled micro-metastases.

Although choroidal melanoma was the commonest primary source for orbital melanoma, cutaneous melanoma is the most likely to have late orbital secondary disease. In a previous study of over 500 metastatic skin cancers, early metastasis $(<3$ years after surgery) was found to be significantly associated with past history of non-melanoma skin cancer, thicker lesions (Breslow depth), and ulcerative melanomas (19). In contrast, a history of non-ulcerative melanoma was found to be associated with late recurrence ( $>8$ years after primary disease), this being consistent with our observation of tendency for orbital metastases of cutaneous melanoma to be a late phenomenon.
Published survival rates for melanoma within the orbit range from 6 to 20 months $(10,13,14)$. There were 52 deaths ( 47 tumorrelated) among our 69 patients with known outcome (75\%), but only $11 / 52(21 \%)$ fell within this previously published survival range, and 7/52 (13\%) had less than 6 months survival. Moreover, $34 / 52$ (65\%) patients survived $>20$ months, and 19/34 (55.8\%) survived $>4$ years. Of the 17 surviving patients in May 2016, 8 (47\%) have survived more than 4 years. Our study would suggest that secondary malignant melanoma within the orbit can follow a relatively indolent course after treatment, with a survival much better than expected-thus making prognosis for this condition hard to predict.

Treatment of secondary orbital melanoma remains controversial and is often palliative (20). Surgery remains the mainstay of treatment, with local resection, debulking, or exenteration being the primary choices. Radiotherapy and chemotherapy can be considered, and their use takes into account life expectancy and the presence of other metastatic diseases (e.g., bony metastases). Local radiotherapy is the most commonly used adjuvant therapy when there are no distant metastases (10), and 16/48 of our patients had local radiotherapy. Chemotherapy was used in $4 / 48$ (9\%) of our patients and played a role when there is systemic metastatic disease at orbital presentation (e.g., bone or liver lesions). The scenario for melanoma chemotherapy is, however, changing rapidly with the advent of immunotherapy; cutaneous and uveal melanomas are biologically distinct, and, as such, they would be expected to require distinct treatments. Immunotherapy for metastatic cutaneous melanoma markedly improves survival, with the most dramatic being ipilimumab and nivolumab combination therapy (21). Several agents have been approved by FDA and NICE for monotherapy, while combination therapies undergo Phase III trials, but there is no evidence yet for the impact these may have in orbital metastases-a potential area for further research.

By contrast, ipilimumab has demonstrated only modest benefits in treating primary uveal melanoma. There are a variety of new agents that might provide benefit in metastatic uveal melanoma; 
these include verteporfin (previously used in wet age-related macular degeneration), arylsulfonamides, and anti-VEGF agents (22). Arylsulfonamides such as KCN1 inhibit hypoxia-inducible factors, thereby depriving cancer cells of their ability to thrive in a hypoxic environment (23). Anti-VEGF agents such as bevacizumab have been postulated as possible treatments because of the high VEGF levels seen in uveal melanoma. Clinical trials relating to these are all in early human phases but have demonstrated significant benefits in mouse models. These potential treatments of secondary orbital melanoma require further investigation, but they may herald a new era where metastatic melanoma is no longer a life-ending diagnosis.

In summary, a high index of suspicion for orbital recurrence should be maintained in any patient with prior history of melanoma, however distant the primary tumor is in site or time. Furthermore, giving a prognosis for orbital melanoma remains problematic due to highly variable survival, and further investigation will be necessary to understand the likely genetic basis of this phenomenon. Currently, surgery remains the mainstay of therapy in melanoma, but development of new immunotherapeutic agents might revolutionize therapy in the years to come.

\section{REFERENCES}

1. de Bustros S, Augsburger JJ, Shields JA, Shakin EP, Pryor CC II. Intraocular metastases from cutaneous malignant melanoma. Arch Ophthalmol (1985) 103:937-40. doi:10.1001/archopht.1985.01050070063031

2. Font RL, Naumann G, Zimmerman LE. Primary malignant melanoma of the skin metastatic to the eye and orbit: report of ten cases and review of the literature. Am J Ophthalmol (1967) 63:738-54. doi:10.1016/0002-9394(67) 91300-1

3. Gündüz K, Shields JA, Shields CL, Eagle RC Jr. Cutaneous melanoma metastatic to the vitreous cavity. Ophthalmology (1998) 105:600-5. doi:10.1016/ S0161-6420(98)94011-8

4. Young SE. Retinal metastases. In: Ryan SJ, editor. Retina. St. Louis: Mosby (1989). p. 591-6.

5. Ramaesh K, Marshall JW, Wharton SB, Dhillon B. Intraocular metastases of cutaneous malignant melanoma: a case report and review of the literature. Eye (1999) 13:247-50. doi:10.1038/eye.1999.60

6. Valenzuela AA, Archibald CW, Fleming B, Ong L, O’Donnell B, Crompton J, et al. Orbital metastasis: clinical features, management and outcome. Orbit (2009) 28:153-9. doi:10.1080/01676830902897470

7. Shields CL, Shields JA, Peggs M. Tumours metastatic to the orbit. Ophthal Plast Reconstr Surg (1988) 4(2):73-80. doi:10.1097/00002341-198804020-00003

8. Shields JA, Shields CL, Brotman HK, Carvalho C, Perez N, Eagle RC Jr. Cancer metastatic to the orbit: the 2000 Robert M. Curts Lecture. Ophthal Plast Reconstr Surg (2001) 17(5):346-54. doi:10.1097/00002341-200109000-00009

9. Goldberg RA, Rootman J, Cline RA. Tumours metastatic to the orbit: a changing picture. Surv Ophthalmol (1990) 35(1):1-24. doi:10.1016/00396257(90)90045-W

10. Zografos L, Ducrey N, Beati D, Schalenbourg A, Spahn B, Balmer A, et al. Metastatic melanoma in the eye and orbit. Ophthalmology (2003) 110(11): 2245-56. doi:10.1016/j.ophtha.2003.05.004

11. Ahmad SM, Esmaeli B. Metastatic tumours of the orbit and ocular adnexa. CurrOpinOphthalmol(2007) 18(5):405-13.doi:10.1097/ICU.0b013e3282c5077c

12. Coupland SE, Sidiki S, Clark BJ, McClaren K, Kyle P, Lee WR. Metastatic choroidal melanoma to the contralateral orbit 40 years after enucleation. Arch Ophthalmol (1997) 115(1):134. doi:10.1001/archopht.1997.01100150136036

13. Orcutt JC, Char DH. Melanoma metastatic to the orbit. Ophthalmology (1988) 95:1033-7. doi:10.1016/S0161-6420(88)33061-7

14. Goldberg RA, Rootman J. Clinical characteristics of metastatic orbital tumours. Ophthalmology (1990) 97:620-4. doi:10.1016/S0161-6420(90) 32534-4

\section{ETHICS STATEMENT}

The local ethics committee ruled that the study did not require ethics approval for retrospective case note review (ROAD17/010).

\section{AUTHOR CONTRIBUTIONS}

AR-study design, data collection, data analysis, preparation of manuscript. SC-data analysis, preparation of manuscript. CJdata analysis, revision of manuscript. DV-clinical assessment of patients, revision of manuscript. GR-study design, clinical assessment of patients, data analysis, revision of manuscript.

\section{FUNDING}

AR gratefully acknowledges funding from Melanoma Focus (Registered Charity No. 1124716) and NIHR Imperial BRC through the Academic Foundation Programme. GR receives funding from the Department of Health's NIHR Biomedical Research Centre for Ophthalmology at Moorfields Eye Hospital and UCL Institute of Ophthalmology.

15. Diener-West M, Reynolds SM, Agugliaro DJ, Caldwell R, Cumming K, Earle JD, et al. Development of metastatic disease after enrolment in the COMS trials for treatment of choroidal melanoma: Collaborative Ocular Melanoma Study Group Report No. 26. Arch Ophthalmol (2005) 123(12):1639-43. doi:10.1001/ archopht.123.12.1639

16. Yaeger T, Brady L. Basis for current major therapies for cancer. 1st ed. In: Lenhard RE Jr, Osteen RJ, Gansler T, editors. Clinical Oncology. (Chap. 5), Atlanta: American Cancer Society (2000). p. 159-229.

17. Connolly G, Wladis E, Masselam K, Weinberg DA. Contralateral orbital melanoma 28 years following enucleation for choroidal melanoma. Orbit (2007) 26:291-4. doi:10.1080/01676830601169189

18. Halliday GM, Patel A, Hunt MJ, Tefany FJ, Barnetson RS. Spontaneous regression of human melanoma/non-melanoma skin cancer: association with infiltrating CD4+ T cells. World J Surg (1995) 19:352-8. doi:10.1007/BF00299157

19. Brauer JA, Wriston CC, Troxel AB, Elenitsas R, Shin DB, Guerry D, et al. Characteristics associated with early and late melanoma metastases. Cancer (2010) 116:415-23. doi:10.1002/cncr.24724

20. Polito E, Leccisotti A. Primary and secondary orbital melanomas: a clinical and prognostic study. Ophthal Plast Reconstr Surg (1995) 11:169-81. doi:10.1097/00002341-199509000-00003

21. Larkin J, Chiarion-Sileni V, Gonzalez R, Grob JJ, Cowey CL, Lao CD, et al. Combined nivolumab and ipilimumab or monotherapy in untreated melanoma. N Engl J Med (2015) 373(1):23-34. doi:10.1056/NEJMoa1504030

22. Luke JJ, Triozzi PL, McKenna KC, Van Meir EG, Gershenwald JE, Bastian BC, et al. Biology of advanced uveal melanoma and next steps for clinical therapeutics. Pigment Cell Melanoma Res (2015) 28(2):135-47. doi:10.1111/ pcmr.12304

23. Burroughs SK, Kaluz S, Wang D, Wang K, Van Meir EG, Wang B. Hypoxia inducible factor pathway inhibitors as anticancer therapeutics. Future Med Chem (2013) 5(5):553-72. doi:10.4155/fmc.13.17

Conflict of Interest Statement: The authors declare that the research was conducted in the absence of any commercial or financial relationships that could be construed as a potential conflict of interest.

Copyright (c) 2017 Rose, Cowen, Jayasena, Verity and Rose. This is an open-access article distributed under the terms of the Creative Commons Attribution License (CC BY). The use, distribution or reproduction in other forums is permitted, provided the original author(s) or licensor are credited and that the original publication in this journal is cited, in accordance with accepted academic practice. No use, distribution or reproduction is permitted which does not comply with these terms. 